\title{
METOPROLOL EFFECT ON FATTY ACIDS COMPOSITION OF CELL MEMBRANE PHOSPHOLIPIDS.
}

\author{
G. Świerczek-Zięba, J. Lodowska, U. Mazurek, S. Kurkiewicz, T. Wilczok*
}

Department of Molecular Biology, Biochemistry and Biopharmacy, Medical University of Silesia,

Narcyzów 1, 41-200 Sosnowiec, Poland

\begin{abstract}
It is quite well known that $\beta$-blockers influence the stability of cell membranes, but the effect of metoprolol on the composition of cell membrane lipids is not established. On the other hand, synchronous culture of Chlorella vulgaris cells, which consists of cells brought to the same developmental stage by cycling lighting, provides a convenient biological model in unidirectional analyses aimed at assessment of effects of xenobiotics on cells. Advantages of the model include short life cycle and possibility to control metabolic processes of the cells across the broad range.

We assessed the effect of metoprolol on fatty acids composition of cell membrane phospholipids in consecutive life cycle stages of Chlorella vulgaris.

Lipids were extracted using a chloroform/methanol method. Phospholipids were precipitated from the chloroform phase with cold acetone and following centrifugation the pellet of phospholipids was hydrolyzed in alkaline solution. Fatty acids were extracted with petroleum ether and then methylated with $\mathrm{BF}_{3}-$ methanol. This protocol produced methyl esters of fatty acids which were subjected to GC-MS analysis.

Metoprolol had no effect on the number of progeny cells of Chlorella vulgaris throughout their life cycle at the concentration range tested $\left(5 \times 10^{-5} \mathrm{M}, 5 \times 10^{-6} \mathrm{M}, 5 \times 10^{-7} \mathrm{M}\right)$. However, we observed stimulation of biological activity of Chlorella cells as measured by spectrophotometry at $\lambda=680 \mathrm{~nm}$. Metoprolol, at the highest concentration, increased phospholipids content in mother cells. Simultaneously, relative amount and saturation level of the fatty acids remained constant.
\end{abstract}




\section{Key words}

fatty acids, phospholipids, biotest, metoprolol, Chlorella vulgaris

\section{Introduction}

The effect of metoprolol on the composition of cell membrane lipids is not well established. However it is known that metoprolol contrary to other $\beta$-blockers, like propranolol does not possess membrane - stabilizing activity (1). These facts drove us to search for differences in the fatty acids content in phospholipids as main components of cell membranes.

In our work we assayed the influence of metoprolol ((1-[isopropylamino]-3-[p-( $\beta$ methoxyethyl)-phenoxy]-2-propanol) tartrate salt) (2) - a drug commonly used in cardiovascular disorders therapies - on chemical composition of fatty acids from phospholipids, in consecutive life cycle phases of Chlorella vulgaris cells.

In our ,short term bioassay" we used synchronous culture of Chlorella vulgaris (3), in which the whole bulk of cells was brought to the same ontogenesis stage by regulated light cycles. This kind of culture which allowed detailed analysis of subcellular processes of Chlorella's growth cycle is relatively short. It takes $24 \mathrm{~h}$ and consists of a $10 \mathrm{~h}$ long light phase and a $14 \mathrm{~h}$ long dark phase. In the $10 \mathrm{~h}$ long light phase, cells grow intensively starting from aplanospores to the maternal cell formation. Following the light phase the process of sporulation takes place in which aplanospores are released and do not develop until the end of the dark phase (4). The beginning of light phase triggers intensive growth of the cells in their next development cycle.

\section{Material and methods}

Algal Culture Chlorella vulgaris cells Beijerinck 1890, strain A-8, harvested at different life cycle stages were analysed as described previously $(3 ; 4)$. Conditions for synchronous cultivation of 
Chlorella cells were as follows: cell concentration $5.0 \times 10^{6}$ per $\mathrm{ml}$ of Lorenzen medium (control), with addition (30 min. prior beginning of cultivation) of $5 \times 10^{-5}, 5 \times 10^{-6}$ and $5 \times 10^{-7} \mathrm{M}$ metoprolol in the experimental cultures; temp. $30^{\circ} \mathrm{C}$, illumination 15000 lux on the reactor surface during 10 hours, followed by 14 hours dark period. During the illumination period, the culture was aerated by air supplemented with $2 \% \mathrm{CO}_{2}$, at the rate of $30 \mathrm{dm}^{3} / \mathrm{h}$ and during the dark period by air without $\mathrm{CO}_{2}$. Chlorella vulgaris cells in the liquid medium were counted in a Bürker's chamber under light microscope and the calculated cell numbers were expressed as number of cells $/ \mathrm{ml}$ of the culture. To measure the general cell biological activity, the cell suspension absorbance at $680 \mathrm{~nm}$ was registered at every hour over the whole cultivation period. The microcolony technique was used to determine the mean number of aplanospores produced by one mother cell. To determine this coefficient Chlorella vulgaris cells taken at $10 \mathrm{~h}$ of the cell cycle were diluted, spaced on solid agar Lorenzen medium and the exact number of aplanospores delivered by each mother cell was determined under the microscope.

Preparation of fatty acid methyl esters. The Chlorella cells were harvested at the successive cell cycle stages $(0 \mathrm{~h}, 4 \mathrm{~h}, 10 \mathrm{~h}, 24 \mathrm{~h})$, by centrifugation of the culture medium at $3500 \mathrm{rpm}$ for $10 \mathrm{~min}$. Lipids were extracted by stirring with chloroform-methanol (2:1, v:v) at room temperature. The extract was concentrated by evaporation and dissolved in $1 \mathrm{~cm}^{3}$ of chloroform. Phospholipids were precipitated from the concentrated lipid fraction by addition of cold acetone to a final concentration of $90 \%$, and then redisolved in petroleum ether, mixed with $1 \mathrm{M} \mathrm{NaOH}(1: 1, \mathrm{v}: \mathrm{v})$ and heated for 30 min. in a boiling water bath. The fatty acids in the petroleum ether layer were esterified using the $\mathrm{BCl}_{3}$-methanol $\left(60^{\circ} \mathrm{C}\right.$ for $10 \mathrm{~min}$.) (5).

GC-MS identification. The methyl esters were identified by gas chromatography-mass spectrometry (GC-MS) with a Hewlett-Packard 5989A MS-Engine mass spectrometer, a Hewlett- 
Packard 5890 series II gas chromatograph, and the Hewlett-Packard ChemStation programme with an NIST/EPA/NIH $75 \mathrm{~K}$ mass spectral database. The gas chromatographic separations were performed with a HP-5MS fused-silica capillary column $(30 \mathrm{~m} \times 0.25 \mathrm{~mm}, 0,25 \mu \mathrm{m}-$ film); the column temperature was $100^{\circ} \mathrm{C}$ for $2 \mathrm{~min}$., increasing to $200^{\circ} \mathrm{C}$ at $5^{\circ} \mathrm{C} / \mathrm{min}$. and holding for $15 \mathrm{~min}$.; the injector temperature was $220^{\circ} \mathrm{C}$, and the helium flow rate was $2 \mathrm{~cm}^{3} / \mathrm{min}$. The MS conditions were as follows: electron energy $70 \mathrm{eV}$; ion source temperature $176^{\circ} \mathrm{C}$; analyser (quad) temperature $100^{\circ} \mathrm{C}$; GC-MS interface temperature $250^{\circ} \mathrm{C}$.

The fatty acids in the phospholipid fraction determined by the GC-MS were identified by comparison of their mass spectra with the mass spectra library and their identity was $95 \% \pm 5 \%$ as compared with the standards.

When areas under the peaks were summed up to show the total fatty acids content at the particular cell developmental stage, the concentration of the given fatty acid was calculated as percents of the total fatty acids content. Triplicate analyses of each phospholipid fraction in 5 separate experiments were carried out.

Statistical analyses. In order to characterize the structure of results pertaining to evaluation of number of cells per $1 \mathrm{~cm}^{3}$ of medium and dynamics of biological activity changes in cells, as determined by spectrophotometric measurement, we presented the following statistics: arithmetic average as a measure of central location and standard deviation as a dispersion measure. Because arithmetic average and standard deviation are normal distribution parameters, goodness of fit of the distribution to normal distribution was assayed with Shapiro-Wilk test. The test mentioned above was performed at a significanse level $\alpha=0.05$.

Analysis of covariance (ANCOVA) was used to compare linear regression coefficients. In order to test parallelism of dynamics of biological activity changes, as determined by spectrophotometry. Regresion equations were fitted for absorbance value, after logarithmic 
transformation, because of skewness. Student's t-test was used to identify the life cycle stage at which differences in absorbance appear between examined cultures and control culture. Homogenity of variance was verified by Levene's test.

Statistical analysis was carried out in Statistica PL software, version 5.1.

\section{Results and discussion}

To assess the influence of metoprolol on Chlorella vulgaris culture density a number of parameters for each tested culture were determined: division coefficient $\left(D_{c}\right)$, growth multiplication factor (GMF) and a relative division coefficient $\left(D_{c x} / D_{c c}\right)$ represents the ratio of $D_{c x}$ for metoprololtreated cultures to a division coefficient for control cultures $\left(\mathrm{D}_{\mathrm{cc}}\right)$ (Table 1).

\section{Table 1}

The number of Chlorella vulgaris cells during the cultivation at successive stages of life cycle and their calculated growth factors

\begin{tabular}{|c|c|c|c|c|}
\hline \multirow{2}{*}{$\begin{array}{c}\text { Parameters of growth of } \\
\text { Chlorella vulgaris }\end{array}$} & \multirow{2}{*}{ Control } & \multicolumn{3}{|c|}{ Metoprolol } \\
\cline { 3 - 5 } & & $\mathbf{5 \times 1 0 ^ { - 5 } \mathbf { M }}$ & $\mathbf{5 \times 1 0 ^ { - 6 }} \mathbf{M}$ & $\mathbf{5 \times 1 0 ^ { - 7 } \mathbf { M }}$ \\
\hline $\mathbf{N}_{\mathbf{t}^{+/}-\mathbf{S D}\left[\times 10^{6} / \mathrm{ml}\right]}$ & $4.83 \pm 0.23$ & $4.93 \pm 0.16$ & $4.95 \pm 0.17$ & $4.73 \pm 0.26$ \\
\hline $\mathbf{N}_{\mathbf{2 4}}+\mathbf{S D}\left[\times 10^{6} / \mathrm{ml}\right]$ & $39.60 \pm 1.30$ & $39.50 \pm 1.52$ & $40.60 \pm 1.48$ & $39.06 \pm 1.34$ \\
\hline $\mathbf{D}_{\mathbf{c}}$ & 8.25 & 8.01 & 8.20 & 8.25 \\
\hline $\mathbf{D}_{\mathbf{c x}} / \mathbf{D}_{\mathbf{c c}}$ & 1.00 & 0.97 & 0.99 & 1.00 \\
\hline $\mathbf{G M F}$ & 8 & 8 & 8 & 8 \\
\hline
\end{tabular}

$\begin{array}{lll}\mathrm{N}_{\mathrm{t}} & - & \text { mean number of cells during light period of growth } \\ \mathrm{N}_{24} & - & \text { mean number of cells in culture at } \mathrm{t}=24 \mathrm{~h} \\ \mathrm{SD} & - & \text { standard deviation } \\ \mathrm{D}_{\mathrm{c}} & - & \text { division coefficient }=\mathrm{N}_{24} / \mathrm{N}_{\mathrm{tl}} \\ \mathrm{D}_{\mathrm{cx}}, \mathrm{D}_{\mathrm{cc}} & - & \text { division coefficient in tested and control culture } \\ \mathrm{GMF} & - & \text { growth multiplication factor (mean cell number obtained from one mother cell determined by } \\ & & \text { the microcolony technique) }(6)\end{array}$

The count in the control culture and the cultures tested with $5 \times 10^{-5}, 5 \times 10^{-6}$ and $5 \times 10^{-7} \mathrm{M}$ metoprolol was constant in the light phase and was estimated as $5 \times 10^{6}$ cells per $\mathrm{ml}$ (Table 1). In the 
control culture Chlorella cells divided into about 8 aplanospores $\left(D_{c}=8.25\right)$ in a single life cycle. Metoprolol - treated cultures had corresponding cell division coefficient $\left(D_{c}\right)$ (Table 1). This relationship was confirmed by a microculture technique. We have also shown that reduction of concentration of xenobiotics resulted in the growth inhibition alleviation. Lodowska et al. (5) employed synchronous Chlorella vulgaris culture to assess the effect on cells at yet another drug used in cardiovascular disorders therapy, that is propranolol. This $\beta$-blocker has greater influence on growth parameters of Chlorella vulgaris culture than metoprolol.

Biological activity of cells, as determined by culture absorbance changes at $\lambda=680 \mathrm{~nm}$, suggests that metoprolol affects cells collected in the second part of the light phase (from $4 \mathrm{~h}$ till $10 \mathrm{~h}$ hour) (Table 2).

The dynamics of cells' biological activity changes in control culture and metoprolol-treated cultures is different for every concentration tested (Table 2). To test parallelism of the dynamics of cells' biological activity changes course, as determined by spectrophotometry (Table 2), the exponential model was fitted. This allowed to obtain the highest correlation coefficients (Fig. 1).

The $5 \times 10^{-5} \mathrm{M}$ concentration of metoprolol showed the highest induction of assessed changes as determined by the growth coefficient and absorbance at $\lambda=680 \mathrm{~nm}$. Therefore, the culture treated with $5 \times 10^{-5} \mathrm{M}$ metoprolol was chosen to determine fatty-acids content.

Mass spectra obtained as the result of GC-MS analysis allowed to identify following fatty acids in the phospholipid fraction of Chlorella cells when cultivated synchronously without and in the presence of $5 \times 10^{-5} \mathrm{M}$ metoprolol: 12:0, 14:0, 15:0, 16:0, 16:1, 16:2, 16:3, 17:0, branched 17:0, 18:0, 18:1, 18:2, 18:3 (Table 3).

Other fatty acids were present at concentrations poorly detectable by the extraction, methylation and separation methods used. 
Table 2

Metoprolol affect on biological activity of Chlorella vulgaris cells, as determined by culture by culture absorbance changes $(\lambda=680 \mathrm{~nm})$ in subsequent light phase hours.

\begin{tabular}{|c|c|c|c|c|}
\hline \multirow{2}{*}{$\begin{array}{l}\text { Hour of } \\
\text { cell cycle }\end{array}$} & \multirow{2}{*}{ Control } & \multicolumn{3}{|c|}{ Metoprolol } \\
\hline & & $5 \times 10^{-5} M$ & $5 \times 10^{-6} M$ & $5 \times 10^{-7} M$ \\
\hline 0 & $0.028 \pm 0.0018$ & $\begin{array}{c}0.028 \pm 0.0019 \\
p=1.0000\end{array}$ & $\begin{array}{c}0.027 \pm 0.0018 \\
p=0.5336\end{array}$ & $\begin{array}{c}0.026 \pm 0.0016 \\
p=0.2237\end{array}$ \\
\hline 1 & $0.033 \pm 0.0012$ & $\begin{array}{c}0.033 \pm 0.0014 \\
p=1.0000\end{array}$ & $\begin{array}{c}0.032 \pm 0.0011 \\
p=0.3473\end{array}$ & $\begin{array}{c}0.030 \pm 0.0026 \\
p=0.1438\end{array}$ \\
\hline 2 & $0.036 \pm 0.0010$ & $\begin{array}{c}0.038 \pm 0.0020 \\
p=0.1963\end{array}$ & $\begin{array}{c}0.036 \pm 0.0011 \\
p=1.0000\end{array}$ & $\begin{array}{c}0.036 \pm 0.0024 \\
p=1.0000\end{array}$ \\
\hline 3 & $0.040 \pm 0.0022$ & $\begin{array}{c}0.043 \pm 0.0019 \\
p=0.1484\end{array}$ & $\begin{array}{c}0.043 \pm 0.0020 \\
p=0.1554\end{array}$ & $\begin{array}{c}0.041 \pm 0.0022 \\
p=0.6074\end{array}$ \\
\hline 4 & $0.046 \pm 0.0024$ & $\begin{array}{c}0.050 \pm 0.0023 \\
p=0.1055\end{array}$ & $\begin{array}{c}0.050 \pm 0.0025 \\
p=0.1162\end{array}$ & $\begin{array}{c}0.048 \pm 0.0015 \\
p=0.2881\end{array}$ \\
\hline 5 & $0.050 \pm 0.0023$ & $\begin{array}{c}0.059 \pm 0.0020 \\
p=0.0069\end{array}$ & $\begin{array}{c}0.058 \pm 0.0017 \\
p=0.0084\end{array}$ & $\begin{array}{c}0.060 \pm 0.0014 \\
p=0.0030\end{array}$ \\
\hline 6 & $0.055 \pm 0.0029$ & $\begin{array}{c}0.067 \pm 0.0022 \\
p=0.0047\end{array}$ & $\begin{array}{c}0.068 \pm 0.0021 \\
p=0.0033\end{array}$ & $\begin{array}{c}0.069 \pm 0.0019 \\
p=0.0022\end{array}$ \\
\hline 7 & $0.065 \pm 0.0029$ & $\begin{array}{c}0.074 \pm 0.0029 \\
p=0.0191\end{array}$ & $\begin{array}{c}0.082 \pm 0.0027 \\
p=0.0018\end{array}$ & $\begin{array}{c}0.088 \pm 0.0028 \\
p=0.0006\end{array}$ \\
\hline 8 & $0.076 \pm 0.0027$ & $\begin{array}{c}0.099 \pm 0.0025 \\
p=0.0004\end{array}$ & $\begin{array}{c}0.096 \pm 0.0021 \\
p=0.0005\end{array}$ & $\begin{array}{c}0.106 \pm 0.0026 \\
p=0.0002\end{array}$ \\
\hline 9 & $0.089 \pm 0.0028$ & $\begin{array}{c}0.111 \pm 0.0023 \\
p=0.0005\end{array}$ & $\begin{array}{c}0.112 \pm 0.0028 \\
p=0.0005\end{array}$ & $\begin{array}{c}0.115 \pm 0.0032 \\
p=0.0004\end{array}$ \\
\hline 10 & $0.106 \pm 0.0029$ & $\begin{array}{c}0.117 \pm 0.0022 \\
p=0.0064\end{array}$ & $\begin{array}{c}0.123 \pm 0.0032 \\
p=0.0024\end{array}$ & $\begin{array}{c}0.143 \pm 0.0024 \\
p=0.0001\end{array}$ \\
\hline
\end{tabular}

The highest concentration of fatty acids from phospholipids of Chlorella vulgaris was detected for acids containing $16(\mathrm{Cl})$ and $18(\mathrm{C} 18)$ atoms of carbon, respectively. When concentrations of all $\mathrm{C} 16$ and $\mathrm{C} 18$ acids were summed up, the participation of the given fatty acid group for the control cells was a follows: $\mathrm{C} 16$ acids at $\mathrm{t}=0 \mathrm{~h}, 4 \mathrm{~h}, 10 \mathrm{~h}$ were $61.3 \%, 56.8 \%, 53.9 \%$, respectively. In the presence of metoprolol at $5 \times 10^{-5} \mathrm{M}$ the participation at $\mathrm{C} 16$ acids was: at $4 \mathrm{~h}-$ 
$57.2 \%$, and at $10 \mathrm{~h}-53.7 \%$. For the group of $\mathrm{C} 18$ acids theirs participation was at $0 \mathrm{~h} 26.7 \%$, at $4 \mathrm{~h}$ $40.6 \%$ and at $10 \mathrm{~h} 44.5 \%$ in the control whereas in the presence at metoprolol at concentration $5 \times 10^{-5} \mathrm{M} 33.6 \%, 43.8 \%$ at $4 \mathrm{~h}$ and $10 \mathrm{~h}$, respectively (Table 4).

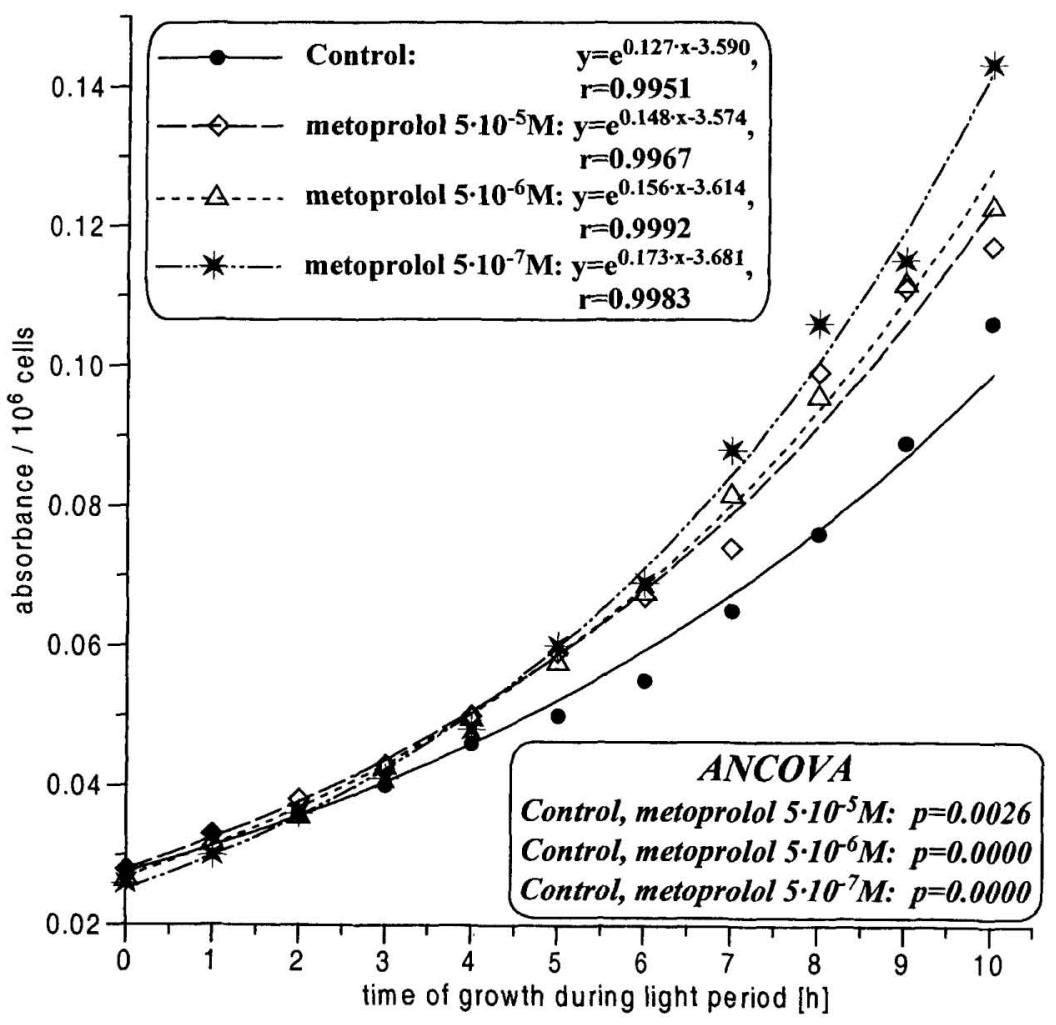

Fig. 1

Assessment of dynamic of absorbance changes $(\lambda=680 \mathrm{~nm})$ in control culture and cultures supplemented with examined concentrations $\left(5 \times 10^{-5} \mathrm{M}, 5 \times 10^{-6} \mathrm{M}, 5 \times 10^{-7} \mathrm{M}\right)$ of metoprolol.

The concentration of 12:0,14:0,15:0,17:0b and 17:0 in control samples decreased during the life cycle, whereas in the presence of metoprolol at concentration $5 \times 10^{-5} \mathrm{M}$ the decrease was lower. 
Table 3

AUPs (area under the peaks) of fatty acids from phospholipids of Chlorella vulgaris calculated per $10^{4}$ cells

\begin{tabular}{|c|c|c|c|c|c|}
\hline \multirow{3}{*}{$\begin{array}{c}\text { Fatty } \\
\text { acid }\end{array}$} & \multicolumn{5}{|c|}{ hour of cell cycle } \\
\hline & \multirow{2}{*}{$\frac{0}{C \text { and } M}$} & \multicolumn{2}{|c|}{4} & \multicolumn{2}{|c|}{10} \\
\hline & & $\mathrm{C}$ & $\mathbf{M}$ & C & $\mathbf{M}$ \\
\hline $12: 0$ & 88 & 45 & 90 & 43 & 58 \\
\hline $14: 0$ & 79 & 40 & 80 & 69 & 160 \\
\hline $15: 0$ & 58 & 0 & 40 & 57 & 73 \\
\hline $16: 0$ & 1040 & 1340 & 1190 & 3970 & 9690 \\
\hline $16: 1$ & 110 & 160 & 120 & 330 & 0 \\
\hline $16: 2$ & 0 & 60 & 0 & 310 & 880 \\
\hline $16: 3$ & 0 & 240 & 0 & 880 & 2300 \\
\hline $17: 0$ & 0 & 0 & 0 & 0 & 120 \\
\hline $17: 0 \mathrm{~b}$ & 0 & 0 & 0 & 0 & 190 \\
\hline 18:0 & 100 & 66 & 120 & 160 & 450 \\
\hline $18: 1$ & 290 & 0 & 0 & 0 & 0 \\
\hline $18: 2$ & 110 & 280 & 250 & 1590 & 3450 \\
\hline $18: 3$ & 0 & 940 & 400 & 2780 & 6580 \\
\hline$C 16$ & 1150 & 1800 & 1310 & 5490 & 12870 \\
\hline C18 & 500 & 1286 & 770 & 4530 & 10480 \\
\hline$S F A$ & 1365 & 1491 & 1520 & 4299 & 10741 \\
\hline$M U F A$ & 400 & 160 & 120 & 330 & 0 \\
\hline PUFA & 110 & 1520 & 650 & 5560 & 13210 \\
\hline$\Sigma F A$ & 1875 & 3171 & 2290 & 10189 & 23951 \\
\hline
\end{tabular}

C - - control culture

M - metoprolol modified culture

C16 - 16-carbon acids

C18 - 18-carbon acids

SFA - saturated fatty acids

MUFA - monounsaturated fatty acids

PUFA - polyunsaturated fatty acids

¿FA - sum area under the peaks of fatty acids from phospholipids of Chlorella vulgaris 
Table 4

The effect of metoprolol at the concentration of $5 \times 10^{-5} \mathrm{M}$ on the composition of phospholipid fatty acids isolated from Chlorella vulgaris cells cultivated synchronously at successive life cycle stages

\begin{tabular}{|c|c|c|c|c|c|}
\hline \multirow{4}{*}{$\begin{array}{l}\text { Fatty } \\
\text { acids }\end{array}$} & \multicolumn{5}{|c|}{ Chlorella vulgaris phospholipid fatty acid share (\%) at the given life } \\
\hline & \multicolumn{5}{|c|}{ hour of cell cycle } \\
\hline & $\mathbf{0}$ & \multicolumn{2}{|c|}{4} & \multicolumn{2}{|c|}{10} \\
\hline & C or $\mathbf{M}$ & $\mathbf{C}$ & $\mathbf{M}$ & $\mathbf{C}$ & $\mathbf{M}$ \\
\hline 12:0 & 4.69 & 1.42 & 3.93 & 0.42 & 0.24 \\
\hline 14:0 & 4.21 & 1.26 & 3.49 & 0.68 & 0.67 \\
\hline 15:0 & 3.09 & 0.00 & 1.75 & 0.56 & 0.30 \\
\hline 16:0 & 55.47 & 42.26 & 51.97 & 38.96 & 40.46 \\
\hline $16: 1$ & 5.87 & 5.05 & 5.24 & 3.24 & 0.00 \\
\hline $16: 2$ & 0.00 & 1.89 & 0.00 & 3.04 & 3.67 \\
\hline $16: 3$ & 0.00 & 7.57 & 0.00 & 8.64 & 9.60 \\
\hline 17:0 & 0.00 & 0.00 & 0.00 & 0.00 & 0.50 \\
\hline $17: 0 \mathrm{~b}$ & 0.00 & 0.00 & 0.00 & 0.00 & 0.79 \\
\hline 18:0 & 5.33 & 2.08 & 5.24 & 1.57 & 1.88 \\
\hline $18: 1$ & 15.47 & 0.00 & 0.00 & 0.00 & 0.00 \\
\hline $18: 2$ & 5.87 & 8.83 & 10.92 & 15.61 & 14.40 \\
\hline $18: 3$ & 0.00 & 29.64 & 17.47 & 27.28 & 27.47 \\
\hline$C 16$ & 61.33 & 56.76 & 57.21 & 53.88 & 53.73 \\
\hline$C 18$ & 26.67 & 40.56 & 33.62 & 44.46 & 43.76 \\
\hline$S F A$ & 72.80 & 47.02 & 66.38 & 42.19 & 44.85 \\
\hline$M U F A$ & 21.33 & 5.05 & 5.24 & 3.24 & 0.00 \\
\hline PUFA & 5.87 & 47.93 & 28.38 & 54.57 & 55.15 \\
\hline
\end{tabular}

$\begin{array}{lll}\mathrm{C} & - & \text { control culture } \\ \mathrm{M} & - & \text { metoprolol modified culture } \\ \mathrm{C} 16 & - & 16 \text {-carbon acids } \\ \mathrm{C} 18 & - & 18 \text {-carbon acids } \\ \mathrm{SFA} & - & \text { saturated fatty acids } \\ \text { MUFA } & - & \text { monounsaturated fatty acids } \\ \text { PUFA } & - & \text { polyunsaturated fatty acids }\end{array}$


The area under the fatty acids spectrum suggests that metoprolol brings about nearly two times higher fatty acids content in phospholipids of the primary cells $(t=10 \mathrm{~h})$ in comparison to the corresponding control culture cells (Table 3). However it does not alter the $\mathrm{C} 16 / \mathrm{C} 18$ ratio and does not influence the saturation level of the analysed fraction.

There were no significant differences in the fatty acids content in phospholipids for control and metoprolol-treated cultures in the vegetative growth phase $(t=4 \mathrm{~h})$. Despite the lack of differences, metoprolol still modifies quantitative ratio of distinct acids in phospholipids extracted from cells at $t=4 \mathrm{~h}$ when compared to control culture (increase in 16:0 percentage, decrease in 18:2 and 18:3 and complete loss of 16:2 and 16:3). Increase in saturation of phospholipids from cells grown in the presence of the xenobiotic during vegetative growth phase may cause cell membranes to become more rigid which could decrease their permeability. It is noteworthy that the length of hydrocarbon chains of fatty acids from phospholipids extracted from cultures at $\mathrm{t}=4 \mathrm{~h}$ treated with metoprolol at $5 \times 10^{-5} \mathrm{M}$ concentration were shorter than those from control cultures.

\section{Conclusions}

As it was stated, the effect of metoprolol as well as propranolol (5) may affect the organization of cell membranes. Fatty acids which are the main constituents of cell membranes show changes in their composition when analyzed in synchronized culture of unicellular green algae in the presence of metoprolol and propranolol. In animal cells where synchronized states of large cell numbers are possible only in cell culture under the influence of chemicals which affect the cell growth and probably the composition of cell membranes, shielding the affect of analyzed drug may be significant. In unicellular green algae cultivated synchronously all cells are at the same stage of development. The composition of the cell membrane is therefore a good model for analyzing the effect of various drugs on the composition of fatty acids in the membrane. As one can see from the 
given results the analyzed concentrations $\left(5 \times 10^{-5} \mathrm{M}, 5 \times 10^{-6} \mathrm{M}, 5 \times 10^{-7} \mathrm{M}\right)$ of metoprolol do not alter the number of progeny of a primary Chlorella vulgaris cell during the life cycle, so it is evidently shown that this drug does not affect the number of aplanospores. Starting from $t=4 \mathrm{~h}$, metoprolol increased the biological activity of Chlorella vulgaris cells as compared to control cultures, what is supported by the increase of absorption at $680 \mathrm{~nm}$ suggesting large changes in chlorophyll production. The highest metoprolol concentration decreased saturation of fatty acids from phospholipids extracted at $t=4 \mathrm{~h}$ when compared to control cultures. Simultaneously, the length of the hydrocarbon chains were shorter. At a concentration of $5 \times 10^{-5} \mathrm{M}$ metoprolol increased the phospholipid content of primary cells $(t=10 \mathrm{~h})$, however, there were not big changes in quantitative ratios of fatty acids and in their saturation level.

Taking into account the above findings one can assume that also in animal cells changes in their membranes can occur as the effect of metoprolol. Thus, the permeability of the cell membrane can be changed, affecting the drug penetration.

\section{References}

1. R. Anderson, G. Ramafi, A.J. Theron: (1996) Biochem. Pharmacol. 52(2): 341-349

2. J. A. Piper: (1986) Beta blockers in textbook for the Clinical Applications of Therapeutic Drug Monitoring, W.J. Taylor, M. H. Dives Cairns Abbott Laboratories, Diagnostic Division, Irwing Texas

3. A. Wilczok, U. Mazurek: (1987) Stud. Biophys. 122: 237

4. U. Mazurek: (1986) Ph. D. Thesis, Silesian Medical Academy, Katowice

5. J. Lodowska, U. Mazurek, S. Kurkiewicz, A. Wilczok, G. Świerczek, I. Tam, A. Pytel, T. Wilczok: (1999) Acta Poloniae Pharmaceutica - Drug Research 56(1): 21

6. A. Wilczok, U. Mazurek, D. Tyrawska, B. Sosak-Świderska: (1994) Pol. Arch. Hydrobiol. 41(1): 123 